\title{
The effectiveness of argumentation based learning and problem based learning models in improving student's argumentation skills about salt hydrolysis concept
}

\author{
Anisa Puspita Sari ${ }^{1}$, Harizon ${ }^{2}$ and Muhammad Haris Effendi- \\ Hasibuan ${ }^{2, *}$ \\ ${ }^{1}$ Chemistry Education Study Program, Postgraduate, Jambi University, Jambi 36361, Indonesia \\ ${ }^{2}$ Departemen of Chemistry Education, Jambi University, Jambi 36361, Indonesia \\ *Corresponding author: MHEH, hariseffendi@unja.ac.id
}

DOI: $10.24114 / j p k i m . v 13 i 3.29928$

Article history:

Received: 24 November 2021

Revised: 01 December 2021

Accepted: 02 December 2021

\begin{abstract}
Learning model that can train students in developing their argumentative skills includes the Argumentation Based Learning ( $A B L)$ and Problem Based Learning ( $P B L)$. This study aimed to see the effectiveness of the $A B L$ and $P B L$ models in improving students' argumentation skills about the concept of salt hydrolysis. The study was conducted in the class XI MIA SMAN 1 Tebo Jambi with a sample consisting of two classes. Some 50 students were recruited purposively to be the participants of this study. Concurrent embedded mix method using two group pretest posttest control group design was used in this study. The results of independent $t$-test showed that $A B L$ was more effective than PBL ( $t=4.864 ; \mathrm{p}$-value $=0.00<0.05)$ in improving the students' argumentation skills. This was supported by the $\mathrm{N}$-gain test of $\mathrm{ABL}$ which was 0.82 and the $\mathrm{N}$-Gain test of PBL was 0.68 . The results of observations revealed that the $A B L$ students had more intensive opportunities to debate their argumentation than those in the PBL class. This was believed as the major factor influencing the difference in the students' argumentation skills.
\end{abstract}

Keywords: argumentation based learning, argumentation skill, problem based learning, salt hydrolysis

\section{Introduction}

Students' understanding of chemistry must have linkages between concepts. If one concept cannot be understood correctly it will hinder the understanding of the next concept. To understand the concept correctly, students need to develop abstract, critical, and analytical thinking skills. This ability includes the ability to argue (Matuk, 2016). According to Pritasari et al. (2016) argumentation plays an important role in developing 
thinking patterns and adding an in-depth understanding of an idea or idea. Argumentation trains students in using their thinking skills so that conceptual understanding is built. The components of Toulmin's argument consist of claim, evidence, warrant, backing, qualifiers, and rebuttal. There are indications that students can submit claims, evidence, and warrants that show students can be said to have argued. This argument can be considered as a constructivist teaching method. Arguments are used to strengthen a claim based on evidence and logical reason (Witri et al. 2020).

Based on the results of interviews with chemistry teachers at SMAN 1 Tebo, it is known that students still have difficulty understanding the concept of salt hydrolysis. While the material for salt hydrolysis requires a strong understanding of the concept. Most students have not been able to argue well. For example, when students are given the phenomenon of " Which one dissolves faster, one tablespoon of salt dissolved in $250 \mathrm{ml}$ of hot water or 250 $\mathrm{ml}$ of plain water ?" students can provide statements correctly, but students cannot provide evidence and reasons that connect scientific statements and evidence. This indicates that students cannot yet argue. Based on these problems, an alternative is needed in the learning process that can improve the quality of the student learning process so that it can help students develop their argumentation skills. One of them is by applying a learning model that can train students' argumentation skills. According to Matuk (2016) argumentation ability can be achieved in a learning atmosphere that stimulates students to carry out argumentative activities.

Learning models that have been applied to improve students' argumentation skills include the Argument Based Science Inquiry (ABSI) learning model that has been used by Budiyono et al. (2016) and shows the results that students' argumentative abilities are in the high category. Nasution (2019) and shows the results that students' argumentative abilities are in the high category. Effendi-Hasibuan et al. (2019) has applied three learning models, namely Jigsaw, TSTS, and DL to improve the argumentation skills of high school students in Jambi. From this study, it was found that these three models succeeded in increasing students' argumentation skills on the reaction rate material, but the jigsaw model was more effective among the three.

In addition to the learning model that has been used in previous research, another learning model that can train students in developing their argumentative skills is a learning model that has been designed to improve students' argumentation skills such as Argumentation Based Learning (ABL). According to Effendi-Hasibuan \& Bakar (2020) ABL has given students greater opportunities to practice their ability to make arguments. $A B L$ involves students in intense argumentative discussions with clear steps, instructions, and time allocation for making claims, evidence, and reasons (CER). Based on research EffendiHasibuan \& Bakar (2020) which uses ABL and socioscientific issues to improve students' argumentation skills in the field of chemistry. It was found that learning using $A B L$ was the most effective between jigsaw and TSTS in improving argumentation skills.

Another learning model used to improve students' argumentation skills is Problem Based Learning. According to Arifin (2015), PBL learning discusses life situations that are around with solutions that are not simple. The teacher's role poses various authentic problems and facilitates students to identify authentic problems, facilitate investigations, and support student learning. This PBL learning model, it helps students improve and enhance cognitive skills and processes. Several studies that apply the PBL learning model include those carried 
out Pritasari et al. (2016) the results show that there is an increase in argumentation ability through the application of the PBL model to students. As well as research Mubarok et al. (2016) the results show that the PBL model with a scientific approach has a strong influence on students' scientific argumentation skills. This is indicated by the effect size value obtained as strong criteria. Based on the results of the study, the $A B L$ and $P B L$ learning models are known to improve students' argumentation skills. However, the $A B L$ learning model is a learning model specifically designed to train students to argue in the learning process. In line with the opinion Effendi-Hasibuan \& Bakar (2020) that the ABL model is deliberately designed to help students develop argumentation skills. While the PBL model does not specifically train students' argumentation skills.

One of the chemical materials that can be used in $A B L$ and PBL learning models to develop students' argumentation skills is salt hydrolysis. The salt hydrolysis material in class $\mathrm{XI}$ is one of the chemical materials that is still considered quite difficult by students because it requires a combination of understanding concepts and mathematical calculations. Therefore, difficulty on this matter can be caused because the student is still actively involved to construct knowledge with the ability to involve the student's argument. Based on the description above, the author wants to see the effectiveness of the ABL and PBL learning models in improving students' argumentation skills on the salt hydrolysis material. The research objectives are; (1) To find out the improvement of students' argumentation skills using the $A B L$ and PBL learning models on the salt hydrolysis material at SMAN 1 Tebo. (2) To find out the difference in increasing students' argumentation skills using the $A B L$ and PBL learning models on the salt hydrolysis material at SMAN 1 Tebo. (3) To find out the causes that affect the differences in the argumentation skills of students in the two classes.

\section{Methods}

This research was conducted at SMAN 1 Tebo Jambi Class XI MIA on salt hydrolysis material for the 2020/2021 academic year. The method used in this research is the mixed method concurrent embedded. The design used in this study was a two-group pretestposttest group design, in which two experimental classes were selected and then given a pretest and posttest to both classes (Table 1). The sampling technique was carried out by purposive sampling and obtained two sample classes, namely class XI MIA 3 as experimental class 1 with 25 students and class XI MIA 2 as experimental class 2 with 25 students.

Table 1

Village in research

\begin{tabular}{c|c|c|c}
\hline Class & Pretest & Treatment & Posttest \\
\hline Experiment 1 & O1 & ABL Models & O2 \\
\hline Experiment 2 & O1 & PBL Models & O2 \\
\hline
\end{tabular}

These research data collection techniques are in the form of test essay test techniques including the capabilities of argument gives the claim, evidence, and reasoning (Table 2). In addition, it also uses an observation sheet on the implementation of the learning model. The data analysis technique used is descriptive, prerequisite test, and hypothesis testing. The prerequisite test used is the normality test or the Shapiro-Wilk test and the homogeneity 
test using the Levene test. To test the hypothesis, the researcher used the t-independent test data analysis technique with a significant level of $=0.05$ or $5 \%$.

Table 2

\begin{tabular}{c|c|c|l}
\multicolumn{2}{c}{ Criteria for argumentation skills rubric (Effendi-Hasibuan et al. 2019) } \\
\hline \multirow{2}{*}{ Skills } & \multirow{2}{*}{ Claim } & Evidence & \multicolumn{1}{c}{$\begin{array}{c}\text { Reasoni } \\
\text { ng }\end{array}$} \\
\hline \multirow{2}{*}{ Level (score) } & & Relevant & Correct and connecting \\
\hline 5 & Correct & Relevant & Correct, not connecting \\
\hline \multirow{2}{*}{3} & Correct & Irrelevant & Correct and connecting \\
\cline { 3 - 4 } & & Relevant & Wrong \\
\cline { 3 - 4 } 2 & Correct & Irrelevant & Correct, not connecting \\
\hline \multirow{2}{*}{2} & Correct & Irrelevant & Wrong \\
\cline { 3 - 4 } & & Wrong & Correct, not connecting \\
\hline 0 & Correct & Wrong & Wrong \\
\hline 0 & Wrong & Wrong & Wrong \\
\hline
\end{tabular}

The steps of the ABL model according to Effendi-Hasibuan \& Bakar (2020) are (1) content delivery, (2) problem or task delivery, (3) individual argumentation, (4) group argumentation, (5) intra-group debates, (6) review. Meanwhile, the steps of the PBL model according to Harahap et al. (2018) are (1) student orientation to problems, (2) organizing students in learning, (3) guiding individual and group investigations, (4) developing and presenting work, (5) analysis and evaluation of the problem-solving process.

\section{Results and Discussion}

Learning in each experimental class was carried out in three meetings. Each class is divided into two shifts namely, shift $A$ and shift $B$ with the allocation of learning time for each meeting is 60 minutes. The data obtained in this study are the students' argumentation skills based on the results of the pretest and posttest. The pretest data of students' argumentation skills can be seen in Table 3.

Table 3

Pretest data of students' argumentation skills

\begin{tabular}{c|c|c|c|c|c|c|c|c}
\hline Learning & Mean & Standard & Mean of & \multicolumn{5}{|c}{ Level of Argumentation } \\
\cline { 5 - 9 } Strategies & Score & deviation & Skill & 1 & 2 & 3 & 4 & 5 \\
\hline ABL & 9.47 & 4.05 & 0.47 & 9.47 & - & - & - & - \\
\hline PBL & 9.60 & 3.89 & 0.48 & 9.60 & - & - & - & - \\
\hline
\end{tabular}

Based on Table 3, it can be seen that the argumentation skills of students in the two experimental classes has an average score with a less significant difference, with the average value of the ABL class of 9.47 and the PBL class of 9.60. This proves that the three classes have the same argumentation ability before being given treatment. The argumentation level of students in the three experimental classes is only at level one. Showed that the students were able to give the claim but have not been able to provide data and why. Posttest data can be seen in Table 4 . 
Table 4

Posttest data of students' argumentation skills

\begin{tabular}{c|c|c|c|c|c|c|c|c}
\hline Learning & Mean & Standard & Mean of & \multicolumn{5}{|c}{ Level of Argumentation } \\
\cline { 5 - 9 } Strategies & Score & deviation & Skill & 1 & 2 & 3 & 4 & 5 \\
\hline $\mathrm{ABL}$ & 83.20 & 9.00 & 4.16 & - & - & 14.80 & 27.73 & 40.67 \\
\hline $\mathrm{PBL}$ & 71.20 & 8.44 & 3.56 & - & 1.60 & 30.80 & 23.47 & 15.33 \\
\hline
\end{tabular}

Based on Table 4, the class that learns to use the ABL model has a higher average score than the class that learns to use the PBL model. In addition, experimental class 1 which applies the $A B L$ model has an average value of 4.16 argumentation ability, in the experimental class 2 which applies the PBL model has an average value of 3.56. The argumentation ability of students at level 5 has a high score in the class taught using the $A B L$ model, which is $40.67 \%$ while in the PBL class it is $15.33 \%$. For level 3 the highest value is in the PBL class and for level 4 the highest value is in the ABL class. In the ABL class, the argumentation skills of students at levels 3 and 4 are $14.80 \%$ and $27.73 \%$, respectively. In the PBL class, the argumentation ability of students at level 2 is $1.60 \%$, while levels 3 and 4 are $30.80 \%$ and $23.47 \%$, respectively. Based on the data on the level of students' argumentation skills, it can be concluded that the experimental class that applies the ABL model has a better argumentation level value than the experimental class that is taught using PBL. To see the spread of students' argumentation levels (Fig 1 and Fig 2).

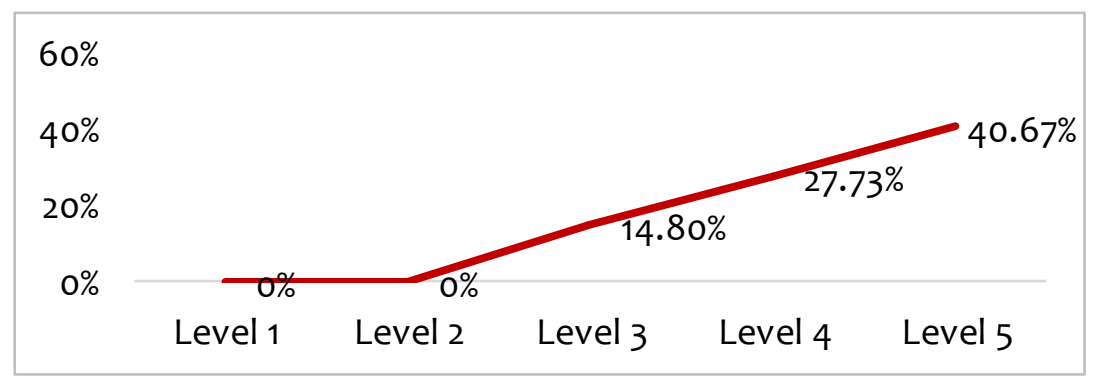

Fig 1. Students' argumentation skills level in the ABL model from data posttest

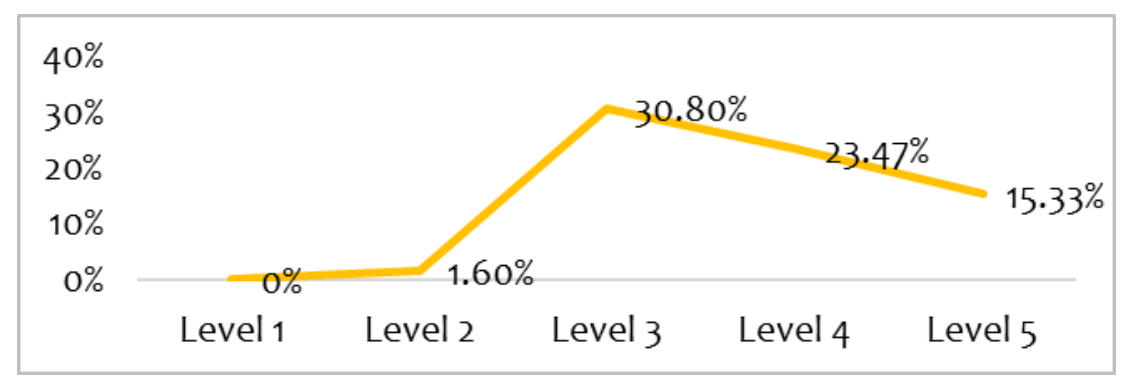

Fig 2. Students' argumentation skills level in the PBL model from data posttest

Based on Fig 1, it can be seen that students' argumentation skills increase with increasing level of argumentation, where level 3 is $14.80 \%$, level 4 is $27.73 \%$ and level 5 is $40.67 \%$. This proves that the students' argumentation skills are good, where the highest percentage is at level 5. In this case, most of the students can provide claims, evidence, and reasoning linking. 
Based on Fig 2, it can be seen that the class taught using the PBL model, the argumentation ability of students is mostly at level 3 with $30.80 \%$ then students at level 4 are $23.47 \%$ and at level 5 are $15.33 \%$. In the PBL class, there are students at level 2 of $1.60 \%$. More students' argumentation ability at level 3 shows that most students have been able to provide claims and evidence but are still wrong or not connecting in giving reason. To see the comparison of each level of argumentation of students in ABL and PBL classes (Fig 3 ).

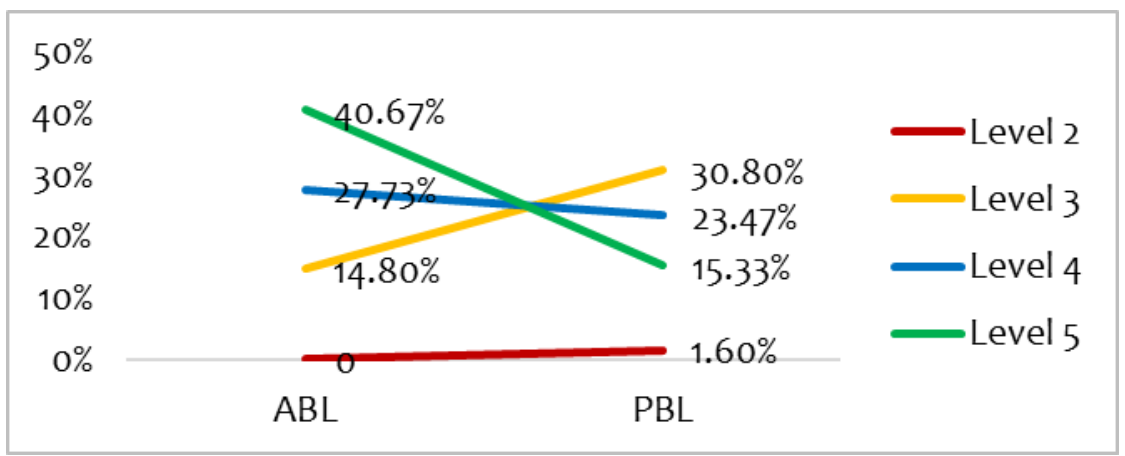

Fig 3. Student argumentation level from data posttest

Furthermore, the $\mathrm{N}$-gain test was carried out to determine the increase in cognitive learning outcomes of students' argumentation abilities after being given treatment. The results of the $\mathrm{N}$ - gain test can be seen in Table 5 .

Table 5

$\mathrm{N}$-gain test results from data pretest and posttest

\begin{tabular}{c|c|c}
\hline Learning Model & $\mathrm{N}$-gain Score & Category \\
\hline $\mathrm{ABL}$ & 0.82 & Tall \\
\hline $\mathrm{PBL}$ & 0.68 & Currently \\
\hline
\end{tabular}

Based on Table 5 shows that the average N-gain score in the ABL class of $0.82(0.82>0.7)$ is included in the high category. In the PBL class, the average N-gain score of $0.68(0,3<0.68$ $<0.7$ ) is included in the medium category (Lestari \& Mujib, 2018). Based on these results, it can be concluded that the use of the ABL learning model is effective in improving students' argumentation skills on the salt hydrolysis material. Meanwhile, the use of the PBL learning model is quite effective in improving students' argumentation skills on the salt hydrolysis material. In line with the research of Humairah et al. (2018) which obtined the results that there is an increase in student learning outcomes who are taught using e-learning media with a Problem Based Learning model on salt hydrolysis material by $68,4 \%$. This can be caused because the $A B L$ model is more intensive in teaching students to argue than the PBL model.

Before testing the hypothesis, a prerequisite test was carried out by testing the normality taken from the Shapiro-Wilk data because the number of samples was $<50$. The test was carried out using SPSS version 20. The data from the pretest and posttest normality test results are summarized in Table 6 and Table 7.

Based on Table 6, the significance value based on Shapiro-Wilk yaitu > 0,05. Seen in the $A B L$ class has a significance value $(0,051>0,05)$ and the PBL class has a sifnificance value 
$(0,059>0,05)$. So it can be concluded that the pretest scores in both experimental classes are normally distributed (Ross \& Willson, 2018).

Table 6

Pretest normality test data

\begin{tabular}{l|l|c|c|c|c|c|c}
\hline \multirow{2}{*}{} & \multirow{2}{*}{ Learning Model } & \multicolumn{3}{|c|}{ Kolmogorov-Smirnov } & \multicolumn{3}{c}{ Shapiro-Wilk } \\
\cline { 3 - 8 } & & Statistic & $\mathrm{df}$ & Sig. & Statistic & $\mathrm{df}$ & Sig. \\
\hline \multirow{2}{*}{ Argument } & $\mathrm{ABL}$ & .155 & 25 & .123 & .920 & 25 & .051 \\
\cline { 2 - 8 } & PBL & .175 & 25 & .048 & .923 & 25 & .059 \\
\hline
\end{tabular}

Table 7

Posttest normality test data

\begin{tabular}{l|l|c|c|c|c|c|c}
\hline \multirow{2}{*}{} & \multirow{2}{*}{ Learning Model } & \multicolumn{3}{|c|}{ Kolmogorov-Smirnov ${ }^{\mathrm{a}}$} & \multicolumn{3}{c}{ Shapiro-Wilk } \\
\cline { 3 - 8 } & & Statistic & $\mathrm{df}$ & Sig. & Statistic & $\mathrm{df}$ & Sig. \\
\hline \multirow{2}{*}{ Argument } & $\mathrm{ABL}$ & .106 & 25 & .200 & .962 & 25 & .455 \\
\cline { 2 - 8 } & $\mathrm{PBL}$ & .144 & 25 & .191 & .944 & 25 & .180 \\
\hline
\end{tabular}

Based on Table 7, the significance value based on Shapiro-Wilk is $>0.05$. Seen in the ABL class has a significance value $(0.455>180)$ and the PBL class has a significance value ( $0.059>$ $0.05)$. So it can be concluded that the posttest scores in both experimental classes are normally distributed (Ross \& Willson, 2018).

After the data obtained from the pretest and posttest values were normally distributed, then $t$-dependent test was performed to determine whether the effectiveness between the $A B L$ and PBL models was significant or not. The data from the independent $t$-test can be seen in Table 8.

Table 8

T-dependent test result data

\begin{tabular}{|c|c|c|c|c|c|c|c|c|}
\hline & \multicolumn{5}{|c|}{ Paired Differences } & \multirow[t]{3}{*}{$\mathrm{t}$} & \multirow[t]{3}{*}{$\mathrm{df}$} & \multirow{3}{*}{$\begin{array}{l}\text { Sig. (2- } \\
\text { tailed) }\end{array}$} \\
\hline & \multirow[t]{2}{*}{ Mean } & \multirow[t]{2}{*}{$\begin{array}{c}\text { Std. } \\
\text { Deviation }\end{array}$} & \multirow[t]{2}{*}{$\begin{array}{l}\text { Std. Error } \\
\text { Mean }\end{array}$} & \multicolumn{2}{|c|}{$\begin{array}{l}\text { 95\% Confidence } \\
\text { Interval of the } \\
\text { Difference }\end{array}$} & & & \\
\hline & & & & Lower & Upper & & & \\
\hline $\begin{array}{l}\text { Pretest_ABL - } \\
\text { Posttest_ABL }\end{array}$ & -73.73 & 6.83 & 1.37 & -76.55 & -70.92 & -54.02 & 24 & .000 \\
\hline $\begin{array}{l}\text { Pretest_PBL- } \\
\text { Posttest_PBL }\end{array}$ & -61.60 & 5.86 & 1.17 & -64.02 & -59.18 & -52.53 & 24 & .000 \\
\hline
\end{tabular}

Based on the data in Table 8, it can be seen that the significance value of the pretest and posttest values in the $A B L$ and $P B L$ classes is $(0.000<0.05)$. This shows that there is a significant difference between the pretest and posttest scores. So it can be concluded that the application of the $\mathrm{ABL}$ and $\mathrm{PBL}$ models to the salt hydrolysis material can improve students' argumentation skills.

The argumentation ability of students in $\mathrm{ABL}$ and PBL classes based on the pretest and posttest scores can be seen as the difference in the average value of the two classes by performing an independent $t$-test. The data from the $t$-independent pretest and posttest 
results are summarized in Table 9 and Table 10. In Table 9 it is known that the significance value of Levene's test for equality of variances is $(0.799>0.05)$, it can be interpreted that the variance of the pretest data between the $A B L$ and PBL models is homogeneous or the same. It is also known that the significance value (2-tailed) is (0.906 > 0.05), so it can be concluded that there is no significant difference between the average pretest scores of students' argumentation abilities in the ABL class and the PBL class (Ross \& Willson, 2018). This shows that students in class $\mathrm{ABI}$ and $\mathrm{PBL}$ have the same initial argumentation ability.

Table 9

Data from independent t-test results from pretest

\begin{tabular}{|c|c|c|c|c|c|c|c|c|c|c|}
\hline & & \multicolumn{2}{|c|}{$\begin{array}{l}\text { Levene's } \\
\text { Test for } \\
\text { Equality of } \\
\text { Variances }\end{array}$} & \multicolumn{7}{|c|}{ t-test for Equality of Means } \\
\hline & & \multirow[t]{2}{*}{$F$} & \multirow[t]{2}{*}{ Sig. } & \multirow[t]{2}{*}{$t$} & \multirow[t]{2}{*}{$\mathrm{df}$} & \multirow[t]{2}{*}{$\begin{array}{l}\text { Sig. (2- } \\
\text { tailed) }\end{array}$} & \multirow[t]{2}{*}{$\begin{array}{l}\text { Mean } \\
\text { Differe } \\
\text { nce }\end{array}$} & \multirow[t]{2}{*}{$\begin{array}{l}\text { Std. Error } \\
\text { Difference }\end{array}$} & \multicolumn{2}{|c|}{$\begin{array}{l}\text { 95\% Confidence } \\
\text { Interval of the } \\
\text { Difference }\end{array}$} \\
\hline & & & & & & & & & Lower & Upper \\
\hline \multirow[t]{2}{*}{ Pretest } & $\begin{array}{l}\text { Equal variances } \\
\text { assumed }\end{array}$ & .066 & .799 & -.119 & 48 & .906 & -.13360 & 1.12211 & -2.3897 & 2.1225 \\
\hline & $\begin{array}{l}\text { Equal variances } \\
\text { not assumed }\end{array}$ & & & -.119 & 47.92 & .906 & -.13360 & 1.12211 & -2.3898 & 2.1226 \\
\hline
\end{tabular}

While in Table 10 it is known that the significance value of Levene's test for equality of variances is $(0.916>0.05)$, it can be interpreted that the posttest data variance between the $\mathrm{ABL}$ and $\mathrm{PBL}$ models is homogeneous or the same. It is also known that the significance value (2-tailed) is $(0.000<0.05)$, so it can be concluded that there is a significant difference between the posttest average value of students' argumentation abilities in the ABL class and the PBL class (Ross \& Willson, 2018). This can be caused by ABL models involving students in arguing that include aspects of the claim, evidence, and reasoning more intensive compared to PBL models.

\section{Table 10}

Data from independent t-test results posttest

\begin{tabular}{|c|c|c|c|c|c|c|c|c|c|c|}
\hline & & \multicolumn{2}{|c|}{$\begin{array}{l}\text { Levene's } \\
\text { Test for } \\
\text { Equality of } \\
\text { Variances }\end{array}$} & \multicolumn{7}{|c|}{ t-test for Equality of Means } \\
\hline & & \multirow[t]{2}{*}{$\mathrm{F}$} & \multirow[t]{2}{*}{ Sig. } & \multirow[t]{2}{*}{$\mathrm{t}$} & \multirow[t]{2}{*}{$\mathrm{df}$} & \multirow[t]{2}{*}{$\begin{array}{l}\text { Sig. (2- } \\
\text { tailed) }\end{array}$} & \multirow[t]{2}{*}{$\begin{array}{l}\text { Mean } \\
\text { Differe } \\
\text { nce }\end{array}$} & \multirow[t]{2}{*}{$\begin{array}{l}\text { Std. Error } \\
\text { Difference }\end{array}$} & \multicolumn{2}{|c|}{$\begin{array}{l}\text { 95\% Confidence } \\
\text { Interval of the } \\
\text { Difference }\end{array}$} \\
\hline & & & & & & & & & Lower & Upper \\
\hline \multirow[t]{2}{*}{ Posttest } & $\begin{array}{l}\text { Equal variances } \\
\text { assumed }\end{array}$ & .011 & .916 & 4.86 & 48 & .000 & 12.000 & 2.46733 & 7.0391 & 16.960 \\
\hline & $\begin{array}{l}\text { Equal variances } \\
\text { not assumed }\end{array}$ & & & 4.86 & 47.80 & .000 & 12.000 & 2.46733 & 7.0385 & 16.961 \\
\hline
\end{tabular}

The causes of differences in the argumentation abilities of students in $A B L$ and PBL classes include differences in how intensively students are taught to argue through the 
stages in the two learning models applied to the two experimental classes. Based on the results of observations on the implementation of the model, the $A B L$ model is more intensive in teaching students to argue than the PBL model which only introduces argumentation questions and how to solve them which is given in the last syntax. This can enable students in the $A B L$ class to have better argumentation skills than the PBL class. According to Devi et al. (2019) the factors that influence studens' argumentation abilities are the opportunity to argue, students' initial abilities (prior knowledge) where students can only give argument according to their initial abilities, and learning experience which means that students will only argue when students know something related to the problem being discussed. According to Effendi-Hasibuan \& Bakar (2020) ABL has provided greater opportunities to practice their ability to make arguments. $A B L$ involves students in intense argumentative discussions with clear steps, instructions, and time allocation for making claims, evidence, and reasons (CER). This includes individual discussions, in groups, and debate activities.

Model $A B L$ is a learning model that is intentionally designed to train and improve students' argumentation skills. This is in line with the opinion Effendi-Hasibuan \& Bakar (2020) that the ABL model is deliberately designed to help students develop argumentation skills. ABL encourages students to use Toulmin Argumentation Pattern's integrated steps promptly on time. Followed by the opportunity to conduct a debate to find a definite answer. According to Purba et al. (2018) student activities affect the magnitude of student learning outcomes. Therefore, learning models that can improve students' cognitive abilities must be integrated into the chemistry curriculum (Pakpahan et al. 2021; Silaban, 2021).

While the PBL learning model focuses on the chosen problem so that learning does not only study the concepts related to the problem but also the scientific method to solve the problem. According to Huda (2016), PBL learning is learning-oriented to understanding a problem. These problems are found mainly in the learning process. PBL is a form of transition from teaching to learning patterns. So, the center of learning lies in the students, not the teacher's way of teaching. But on the other hand, this way of learning is still difficult for students to accept with a short study time allocation (60 minutes) so that students need to get used to it. Based on the results of research Effendi-Hasibuan \& Bakar (2020) which uses $A B L$ and socioscientific issues to improve students' argumentation skills in the field of chemistry. It was found that learning using $A B L$ was the most effective between jigsaw and TSTS in improving argumentation skills.

\section{Conclusion}

Based on the results of the research and discussion, it can be concluded as follows: (1) The application of the $A B L$ and $P B L$ learning models to the salt hydrolysis material can improve the argumentation skills of students at SMA Negeri 1 Tebo, which is indicated by the $\mathrm{N}$-gain value that increases from pretest to posttest and test results $\mathrm{t}$-dependent which shows that there is a significant difference in the average pretest and posttest scores of the two classes $(0.000<0.05)$. (2) there is a difference increased skills argumentation students after application of $A B L$ and $P B L$ learning model on the material salt hydrolysis in SMA Negeri 1 Tebo, which indicated an increase in test results of the t-independent pre-test with significance $(0.906>0.05)$ and posttest with significance $(0.000<0.05)$. (3) The causes that 
affect the difference in the argumentation skills of students who learn to use the $A B L$ and PBL models are in the ABL class, the argumentation activity of students is more intensive than students who learn to use the PBL model. The intensity of arguing in the ABL class is better than the PBL class due to the different learning stages between the two classes.

\section{Acknownledgment}

The researcher would like to thank all those who have participated, especially the chemistry teacher and class XI MIA SMAN 1 Tebo students for their contribution and cooperation in the research.

\section{References}

Arifian, F. D. (2015). Penilaian autentik sebagai pemandu pembelajaran. Jurnal Pendidikan dan Kebudayaan Missio, 7(1), 133-141.

Budiyono, A. (2016). Pengaruh penerapan model pembelajaran argument based science inquiry (ABSI) terhadap peningkatan kemampuan berargumentasi siswa SMA. Wacana Didaktika, 4(1), 84-93. Doi:10.31102/wacanadidaktika.4.1.84-93

Devi, N. D. C., VH, E. S., \& Indriyanti, N. Y. (2019). Analysis of high school students' argumentation ability in the topic of buffer solution. JKPK (Jurnal Kimia dan Pendidikan Kimia), 3(3), 141-151. DOl:10.20961/jkpk.v3i3.23308

Effendi-Hasibuan, M. H., \& Bakar, A. (2020). Skills to argue: Using argument-based learning $(A B L)$ and socio-scientific issues to promote university students' argumentation skills in chemistry. Journal of Physics: Conference Series, 1567, 022042. DOI:10.1088/17426596/1567/2/022042

Effendi-Hsb, M. H., \& Sulistyo, U. (2019). Promoting Indonesian secondary school students' argumentation skills in the concept of chemistry reaction-rate: a comparative effect of three cooperative learning strategies. Journal of Physics: Conference Series, 1317, 012143. DOI:10.1088/1742-6596/1317/1/012143

Harahap, N.M., Hutabarat, W., \& Silaban, S. (2018). The effect of model problem based learning (PBL) assistance of prezi media on student learning outcomes in colloid materials. Advances in Social Science, Education and Humanities Research, 200, 456-458

Huda, M. (2016). Model-model pembelajaran dan pembelajaran isu-isu metodis dan paradigmatis. Yogyakarta: Celeban Timur.

Humairah, N., Damanik, M., \& Eddiyanto, E. (2018). The effect of e-learning media application using problem based learning models to activities and results of student learning in salt hydrolysis subject. Jurnal Pendidikan Kimia, 10(3), 397-402. DOI:10.24114/jpkim.v12i3.21160

Lestari, Y., \& Mujib, M. (2018). Kemampuan berpikir kritis matematis melalui model education coins of mathematics competition (E-COC). Desimal: Jurnal Matematika, 1(3), 265-274.

Matuk, C. (2016). The learning affordances of augmented reality for museum exhibits on human health. Museums \& Social Issues, 11(1), 73-87. DOI:10.1080/15596893.2016.1142815

Mubarok, O. S., Muslim, M., \& Danawan, A. (2016). Pengaruh model pembelajaran berbasis masalah dengan pendekatan saintifik terhadap kemampuan argumentasi ilmiah siswa SMA pada materi pengukuran. Prosiding Seminar Nasional Pendidikan Sains, 3, 381-388. 
Nasution, E. S. (2019). Peningkatan keterampilan berargumentasi ilmiah pada siswa melalui model pembelajaran argument-driven inquiry (ADI). Jurnal Eksakta Pendidikan, 3(2), 100108. DOI:10.24036/jep/vol3-iss1/375

Pakpahan, D. N., Situmorang, M., Sitorus, M., \& Silaban, S. (2021). The Development of Project-Based Innovative Learning Resources for Teaching Organic Analytical Chemistry. Advances in Social Science, Education and Humanities Research, 59, 782-788.

Pritasari, A. C., Sri, D., \& Riezky, M. P. (2016). Peningkatan kemampuan argumentasi melalui penerapan model problem based learning pada siswa kelas X MIA 1 SMA Batik 2 Surakarta Tahun Pelajaran 2014/2015. Jurnal Pendidikan Biologi, 8(1), 1-7.

Purba, D. N., Damanik, M., Silaban, S., \& Simatupang, L. (2018). The difference of student 's activities and learning outcome with problem based learning using macromedia flash and handout. Jurnal Pendidikan Kimia, 10(3), 403-408. DOl:10.24114/jpkim.v10i3.12704

Ross, A., \& Willson, V. L. (2018). Basic and advanced statistical tests: Writing results sections and creating tables and figures. Springer.

Silaban, S. (2021). Pengembangan program pengajaran. Yayasan Kita Menulis.

Witri, E., Ngatijo, N., \& Effendi-Hasibuan, M. H. (2020). Development of electronic student worksheets based on toulmin argumentation patterns to improve argumentation skills in basic acid materials. Jurnal Pendidikan Kimia, 12(3), 116-123. DOl:10.24114/jpkim.v12i3.21160 